\title{
FAKTOR YANG BERHUBUNGAN DENGAN PRAKTIK PEMERIKSAAN PAYUDARA SENDIRI (SADARI) PADA REMAJA
}

\author{
Seri Wahyuni, Lola Meyasa \\ Poltekkes Kemenkes Palangka Raya, Jl. G. Obos No. 30, 32 Palangka Raya 73111 , Kalimantan Tengah, 081349189511 \\ adilahidayat@gmail.com, lolameyasa@gmail.com
}

\begin{abstract}
ABSTRAK
Kanker payudara merupakan salah satu penyebab utama kematian dan jenis kanker yang lebih banyak terjadi pada wanita di Indonesia. Jumlah penderita kanker payudara semakin meningkat dan mulai banyak menyerang remaja. Adanya kecenderungan peningkatan jumlah penderita kanker, maka perlu dilakukan upaya untuk pencegahannya dengan melaksanakan program deteksi dini kanker payudara yang dikenal dengan metode SADARI (pemeriksaan payudara sendiri). Tujuan penelitian adalah menganalisis hubungan antara pengetahuan, akses informasi dan dukungan keluarga terhadap praktik SADARI pada remaja putri. Penelitian ini merupakan penelitian eksplanatori dengan pendekatan cross sectional. Sampel penelitian berjumlah 108 orang remaja putri usia 15-21 tahun dengan random sampling tekhnik . Hasil penelitian menunjukkan sebagian besar remaja putri memiliki pengetahuan baik $47,2 \%$, akses informasi baik $53,7 \%$, dukungan keluarga $68,5 \%$. Ada hubungan pengetahuan dan dukungan keluarga terhadap praktik pemeriksaan payudara sendiri $(p=0,000$ dan $p=0,003)$
\end{abstract}

Kata kunci : SADARI; pengetahuan; akses informasi; dukungan keluarga

\section{THE RELATED FACTORS TO THE SELF-BREAST EXAMINATION PRACTICE IN ADOLESCENTS}

\begin{abstract}
Cancer is one of the leading causes of death and the type of cancer that is more common in women is breast cancer. The number of breast cancer sufferers is increasing and many are starting to attack teenagers. An increase in the number of cancer patients, it is necessary to make efforts for prevention, namely breast self-examination (BSE). The purpose of the study was to analyze the relationship between knowledge, access to information and family support for breast selfexamination in young women. This research is an explanatory research with cross sectional approach. The research sample consisted of 108 young women aged 15-21 years. Random sampling technique was used in this study. The results showed that most young women had good knowledge $47.2 \%$, good access to information $53.7 \%$, and family support $68.5 \%$. The related variables were knowledge $(p=0,000)$ and family support $(p=0.003)$.
\end{abstract}

Keywords : BSE; knowledge; information access; support family 


\section{LATAR BELAKANG}

Kanker adalah penyakit akibat pertumbuhan tidak normal dari sel-sel jaringan tubuh yang berubah menjadi sel kanker. Dalam perkembangannya, sel-sel kanker ini dapat menyebar ke bagian tubuh lainnya sehingga dapat menyebabkan kematian. Kanker payudara (KPD) merupakan keganasan pada jaringan payudara yang dapat berasal dari epitel duktus maupun lobulusnya. Kanker payudara merupakan salah satu jenis kanker terbanyak di Indonesia (Yayasan Kanker Indonesia, 2012)

Berdasarkan Pathological

Based

Registration di Indonesia, KPD menempati urutan pertama dengan frekuensi relatif sebesar 18,6\%. Badan Registrasi Kanker Perhimpunan Dokter Spesialis Patologi Indonesia (IAPI) dan Komite Penanggulangan Kanker Indonesia, diperkirakan angka kejadiannya di Indonesia adalah 12/100.000 wanita, sedangkan di Amerika adalah sekitar 92/100.000 wanita dengan mortalitas yang cukup tinggi yaitu 27/100.000 atau $18 \%$ dari kematian yang dijumpai pada wanita. Penyakit ini juga dapat diderita pada laki -laki dengan frekuensi sekitar $1 \%$. Di Indonesia, lebih dari $80 \%$ kasus ditemukan berada pada stadium yang lanjut, dimana upaya pengobatan sulit dilakukan. Oleh karena itu perlu pemahaman tentang upaya pencegahan, diagnosis dini, pengobatan kuratif maupun paliatif serta upaya rehabilitasi yang baik, agar pelayanan pada penderita dapat dilakukan secara optimal (Komite Penanggulangan Kanker Payudara, 2015)

Menurut World Health Organization (WHO, 2012), di Indonesia angka kematian yang disebabkan oleh kanker payudara menempati urutan ke-10 setelah kanker paru, sedangkan berdasarkan Riset Kesehatan Dasar (Badan Litbang Kemenkes RI, 2013) prevalensi tumor/kanker di Indonesia adalah 1,4 per 1000 penduduk atau sekitar 330.000 orang. Menurut data GLOBOCAN IARC tahun 2012 diketahui bahwa kanker payudara merupakan penyakit kanker dengan persentase kasus baru (setelah dikontrol oleh umur) tertinggi, yaitu sebesar
43,3\%, dan persentase kematian (setelah dikontrol oleh umur) akibat kanker payudara sebesar 12,9\% (Kemenkes, 2015). Kanker payudara merupakan penyebab kematian paling tinggi bagi perempuan di Indonesia dan dari tahun ke tahun Jumlah penderita semakin bertambah dan tidak hanya menyasar perempuan berusia lanjut. Pada beberapa tahun terakhir, kanker payudara mulai menyerang kalangan perempuan muda, yaitu remaja.

Faktor penyebabnya diduga karena perubahan gaya hidup seperti kebiasaan makan makanan cepat saji, seringnya terpapar radiasi dari media elektronik dan perubahan kondisi lingkungan. Penyebab lain tingginya angka kejadian kanker payudara ini adalah karena terbatasnya pengetahuan masyarakat tentang bahaya dari kanker payudara, tandatanda dini, faktor risiko dan cara penanggulangannya (Yayasan Kanker Indonesia, 2012).

Adanya kecenderungan peningkatan jumlah penderita kanker, maka perlu dilakukan upaya untuk pencegahannya, Kemenkes RI telah melaksanakan program deteksi dini kanker payudara yang dikenal dengan metode SADARI (pemeriksaan payudara sendiri). Sadari adalah pemeriksaan payudara sendiri yang bertujuan untuk mengetahui ada tidaknya kanker dalam payudara wanita (Olfah, 2013).

SADARI perlu dilakukan oleh wanita usia 20 tahun atau lebih setiap bulannya yaitu pada hari ke-7 atau ke-10 setelah selesai haid. Seiring berjalan waktu, penyakit ini mulai mengarah ke usia lebih muda, maka usia remaja (13-20 tahun) juga perlu untuk melakukan SADARI secara rutin sebagai upaya pencegahan dan deteksi dini (American Cancer Society, 2011).

Hasil studi pendahuluan yang dilakukan oleh peneliti terhadap 20 siswi di sekolah Kota Palangka Raya, didapatkan bahwa 17 dari 20 remaja tersebut diantaranya sudah mengetahui tentang gambaran kanker payudara tetapi belum mengetahui tentang cara melakukan SADARI. Sehingga peneliti tertarik untuk melakukan penelitian tentang pengetahuan, akses informasi dan dukungan keluarga 
terhadap pemeriksaan payudara sendiri (SADARI) pada remaja putri.

\section{METODE}

Jenis penelitian yang digunakan dalam penelitian ini adalah penelitian explanatory dengan pendekatan cross sectional study. Penelitian ini bertujuan menganalisis hubungan antara pengetahuan, akses informasi dan dukungan keluarga terhadap praktik pemeriksaan payudara sendiri (SADARI) pada remaja putri di Kota Palangka Raya. Populasi dalam penelitian ini adalah remaja putri di Kota Palangka Raya sejumlah 108 orang dengan tekhnik random sampling. Instrumen penelitian yang digunakan adalah kuesioner. Analisis data menggunakan analisis univariat dan bivariat (uji chi-square)

\section{HASIL}

Analisis univariat digunakan untuk melihat gambaran karakteristik distribusi frekuensi karakteristik (umur, pendidikan) dan pengetahuan, akses informasi, dukungan keluarga dan praktik SADARI (Tabel 1)

Tabel 1. Distribusi Frekuensi Praktik SADARI, Usia, Pendidikan, Pengetahuan, Akses Informasi dan Dukungan Keluarga $(n=108)$

\begin{tabular}{lcc}
\hline Variabel & Frekuensi & Persentase (\% \\
\hline Praktik SADARI & & \\
$\quad$ Tidak Pernah & 71 & 65,7 \\
$\quad$ Rutin & 37 & 34,3 \\
Usia & & \\
$\quad$ Remaja Awal & 36 & 33,3 \\
$\quad$ Remaja Akhir & 72 & 66,7 \\
$\begin{array}{l}\text { Pendidikan } \\
\text { SMP/Sederajat }\end{array}$ & 55 & 50,9 \\
$\quad$ SMA/Sederajat & 53 & 49,1 \\
$\begin{array}{l}\text { Pengetahuan } \\
\text { Kurang }\end{array}$ & 15 & 13,9 \\
$\quad$ Cukup & 42 & 38,9 \\
$\quad$ Baik & 51 & 47,2 \\
Akses Informasi & & \\
$\quad$ Kurang Baik & 50 & 46,3 \\
$\quad$ Baik & 58 & 53,7 \\
$\begin{array}{l}\text { Dukungan } \\
\text { Keluarga }\end{array}$ & 34 & 31,5 \\
$\quad$ Tidak Ada & 74 & 68,5 \\
$\quad$ Ada & & \\
\hline & &
\end{tabular}

Tabel 1 menunjukkan bahwa sebagian besar remaja tidak pernah melakukan praktik SADARI $65,7 \%$, usia paling banyak remaja akhir $66,7 \%$, pendidikan SMP/Sederajat 50,9\%, pengetahuan baik $47,2 \%$, akses informasi baik $53,7 \%$ dan dukungan keluarga $68,5 \%$.

Anlisis bivariate dilakukan untuk mengetahui hubungan pengetahuan, akses informasi dan dukungan keluarga terhadap praktik pemeriksaan payudara sendiri (SADARI) pada remaja putri (Tabel 2).

Tabel 2. Hubungan Pengetahuan dengan Pemeriksaan Payudara Sendiri (SADARI) $(n=108)$

\begin{tabular}{lccccccc}
\hline \multirow{2}{*}{$\begin{array}{l}\text { Penge- } \\
\text { tahuan }\end{array}$} & \multicolumn{6}{c}{$\begin{array}{c}\text { Tidak } \\
\text { Pernah }\end{array}$} & \multicolumn{2}{c}{ Rutin } & \multicolumn{2}{c}{ Total } & \multirow{2}{*}{$\begin{array}{c}\text { p- } \\
\text { value }\end{array}$} \\
\cline { 2 - 7 } & $\mathbf{f}$ & $\%$ & $\mathbf{f}$ & $\%$ & $\mathbf{f}$ & $\%$ & \\
\hline Kurang & 14 & 93,3 & 1 & 6,7 & 15 & 100 & 0,015 \\
Baik & 57 & 61,3 & 36 & 38,7 & 93 & 100 & \\
\hline Total & 71 & 65,7 & 37 & 34,3 & 108 & 100 & \\
\hline
\end{tabular}

Tabel 2. menunjukkan bahwa responden dengan pengetahuan kurang sebagian besar tidak pernah praktik SADARI (93.3\%), sedangkan responden dengan pengetahuan baik sebagian besar tidak pernah praktik SADARI (61.3\%). Hasil analisis uji chi-square menunjukkan bahwa pvalue 0,015 secara statistik berarti menunjukkan ada hubungan bermakna antara pengetahuan dengan praktik pemeriksaan payudara sendiri (SADARI) pada remaja putri di Kota Palangka Raya.

Untuk mengetahui hubungan akses informasi dengan praktik SADARI digambarkan pada tabel 3 berikut ini ;

Tabel 3. Hubungan Akses Informasi dengan Pemeriksaan Payudara Sendiri (SADARI) $(n=108)$

\begin{tabular}{|c|c|c|c|c|c|c|c|}
\hline \multirow{3}{*}{$\begin{array}{c}\text { Akses } \\
\text { inform } \\
\text { asi }\end{array}$} & \multicolumn{6}{|c|}{ Praktik SADARI } & \multirow{3}{*}{$\begin{array}{c}p- \\
\text { value }\end{array}$} \\
\hline & \multicolumn{2}{|c|}{$\begin{array}{c}\text { Tidak } \\
\text { Pernah }\end{array}$} & \multicolumn{2}{|c|}{ Rutin } & \multicolumn{2}{|c|}{ Total } & \\
\hline & $f$ & $\%$ & $f$ & $\%$ & $f$ & $\%$ & \\
\hline Kurang & 37 & 74 & 13 & 26 & 50 & 100 & 0,093 \\
\hline Baik & 34 & 58,6 & 24 & 41,4 & 58 & 100 & \\
\hline Total & 71 & 65,7 & 37 & 34,3 & 108 & 100 & \\
\hline
\end{tabular}


Tabel 3. menunjukkan bahwa responden dengan akses informasi kurang sebagian besar tidak pernah praktik SADARI (74\%), sedangkan responden dengan akses informasi baik sebagian besar tidak pernah praktik SADARI (58.6\%). Hasil analisis uji chi-square menunjukkan bahwa pvalue 0,093 secara statistik berarti menunjukkan tidak ada hubungan bermakna antara akses informasi dengan praktik pemeriksaan payudara sendiri (SADARI) pada remaja putri di Kota Palangka Raya.

Untuk mengetahui hubungan dukungan keluarga dengan praktik SADARI digambarkan pada tabel 4 berikut ini;

Tabel 4. Hubungan Dukungan Keluarga dengan Pemeriksaan Payudara Sendiri (SADARI) $(n=108)$

\begin{tabular}{lccccccc}
\hline \multirow{2}{*}{$\begin{array}{c}\text { Dukungan } \\
\text { keluarga }\end{array}$} & \multicolumn{6}{c}{ Praktik SADARI } & \multicolumn{2}{c}{$\begin{array}{c}\text { Tidak } \\
\text { Pernah }\end{array}$} & \multicolumn{2}{c}{ Rutin } & \multicolumn{2}{c}{ Total } & $\begin{array}{c}\text { p- } \\
\text { value }\end{array}$ \\
\cline { 2 - 7 } & $\mathbf{f}$ & $\%$ & $\mathbf{f}$ & $\%$ & $\mathbf{f}$ & $\%$ & \\
\hline Tidak ada & 30 & 88,2 & 4 & 11,8 & 34 & 100 & 0,001 \\
ada & 41 & 55,4 & 33 & 44,6 & 74 & 100 & \\
\hline Total & 71 & 65 & 37 & 34,3 & 108 & 100 & \\
\hline
\end{tabular}

Tabel 4. menunjukkan bahwa responden yang tidak ada dukungan keluarga sebagian besar tidak pernah praktik SADARI $(88,2 \%)$, sedangkan responden yang mendapatkan dukungan keluarga sebagian besar tidak pernah praktik SADARI $(55,4 \%)$. Hasil analisis uji chisquare menunjukkan bahwa $p$ value 0,001 secara statistik berarti menunjukkan ada hubungan bermakna antara dukungan keluarga dengan praktik pemeriksaan payudara sendiri (SADARI) pada remaja putri di Kota Palangka Raya

\section{PEMBAHASAN}

Pengetahuan adalah hasil penginderaan manusia, atau suatu hasil tahu seseorang terhadap objek melalui indera yang dimilikinya (mata, hidung, telinga, dan sebagainya). Pengetahuan merupakan domain yang sangat penting untuk terbentuknya tindakan seseorang (Notoatmodjo, 2012). Tindakan yang akan didasari oleh pengetahuan akan lebih lama bertahan dibandingkan yang tidak didasari oleh pengetahuan. Jika seseorang memiliki pengetahuan yang baik tentang pentingnya pemeriksaan payudara sendiri (SADARI) untuk mendeteksi adanya massa payudara akan menimbulkan respon yang baik dan rutin melakukan praktik pemeriksaan payudara sendiri (SADARI). Berdasarkan uji bstatistik yang dilakukan $p$-value $=0,000 \quad(p<0,005)$ hal ini berarti menunjukkan bahwa ada hubungan antara pengetahuan terhadap praktik pemeriksaan payudara sendiri pada remaja putri di Kota palangka Raya. Artinya semakin baik pengetahuan remaja putri maka akan semakin baik praktik pemeriksaan payudara sendiri (SADARI). Hal ini didukung oleh penelitian yang menunjukkan bahwa ibu rumah tangga yang memiliki pengetahuan kurang baik tentang SADARI, cenderung untuk tidak melakukan SADARI, sedangkan ibu rumah tangga yang memiliki pengetahuan SADARI baik cenderung sering melakukan SADARI (Arafah \& Notobroto, 2017). Hal ini juga didukung oleh penelitian yang menguji pengetahuan santriwati tentang pemeriksaan payudara sendiri (SADARI) dengan praktik pemeriksaan payudara sendiri (SADARI) yang menunjukkan hasil uji 0,015 ( $p<$ 0,005 ) yang berarti ada hubungan bermakna pengetahuan dengan praktik pemeriksaan payudara sendiri (SADARI) pada santriwati Pondok Pesantren Al Ishlah Tembalang (Novasari et al., 2016).

Berdasarkan hasil uji bivariat menunjukkan bahwa akses informasi remaja putri dengan praktik pemeriksaan payudara sendiri (SADARI) pada remaja di Kota Palangka Raya dengan pvalue $=0,093$, yang berarti bahwa tidak ada hubungan bermakna anatar akses informasi dengan praktik pemeriksaan payudara sendiri (SADARI). Hal ini sejalan juga dengan hasil penelitian yang dilakukan oleh Apriliyana (2017) yang menunjukkan $p$-value $=0,301$ yang artinya secara statistic tidak terdapat hubungan yang bermakna antara paparan media informasi dengan praktik SADARI pada remaja putrid di SMA Negeri 3 Semarang (Apriliyana et al., 2017).

Dukungan keluarga didefinisikan sebagai informasi verbal atau non verbal, saran, bantuan 
yang nyata atau tingkah laku yang diberikan oleh orang-orang yang akrab dengan subjek di dalam lingkungannya atau yang berupa kehadiran dan hal hal yang dapat memberikan keuntungan emosional dan berpengaruh pada tingkah laku penerimanya. Dalam hal ini orang yang merasa memperoleh dukungan secara emosional merasa lega karena diperhatikan, mendapat saran atau kesan yang menyenangkan pada dirinya (Napitulu, 2010).

Hasil uji statistik menunjukkan bahwa pvalue $=0,001$ menunjukkan bahwa ada hubungan antara dukungan keluarga dengan praktik pemeriksaan payudara sendiri (SADARI) pada remaja putri di Kota Palangka Raya. Semakin baik dukungan keluarga, maka semakin baik praktik pemeriksaan baik praktik pemeriksaan payudara sendiri (SADARI) atau semakin kurang dukungan keluarga maka akan semakin kurang pula praktik pemeriksaan payudara sendiri (SADARI). Dukungan keluarga merupakan penguat dari pembentukan perilaku seseorang, dimana setiap dukungan dan interaksi menghasilkan hubungan timbal balik yang saling mempengaruhi pola perilaku masing-masing individu satu dengan yang lainnya. Orang tua/keluarga memberikan arahan kepada pola perilaku yang disetujui secara sosial, di dalam mendidik anak-anaknya. Hal ini sejalan dengan penelitian Apriliyana (2017) yang menunjukkan hasil uji statistik pvaluei $=0,0001$ maka dapat disimpulkan ada hubungan yang signifikan antara dukungan orangtua dengan praktik SADARI (Apriliyana et al., 2017).

\section{KESIMPULAN DAN SARAN}

Ada hubungan antara pengetahuan dan dukungan keluarga dengan praktik pemeriksaan payudara (SADARI) pada remaja putri di Kota Palangka Raya. Tenaga kesehatan bekerjasama dengan pihak sekolah untuk melakukan edukasi tentang pemeriksaan payudara sendiri (SADARI) secara periodik.

\section{REFERENSI}

American Cancer Society. (2011). American Cancer Society Recommendations for the Early Detection of Breast Cancer. https://www.cancer.org/cancer/breastcancer/screening-tests-and-earlydetection/american-cancer-societyrecommendations-for-the-early-detectionof-breast-cancer.html

Apriliyana, D., Agushybana, F., Mawarni, A., \& Nugroho, D. (2017). Hubungan Persepsi, Paparan media Informasi dan Dukungan Orang Tua dengan Praktik pemeriksaan Payudara Sendiri (SADARI) pada Remaja Putri di SMA Negeri 3 Semarang. Jurnal Kesehatan Masyarakat (e-Journal), 5(4), https://ejournal3.undip.ac.id/index.php/jkm/ articl.

Arafah, A. B. R., \& Notobroto, H. B. (2017). Faktor Yang Berhubungan Dengan Perilaku Ibu Rumah Tangga Melakukan Pemeriksaan Payudara Sendiri (SADARI). The Indonesia Journal of Public Health, 12(2), $\quad$ https://ejournal.unair.ac.id/IJPH/article/view/75.

Badan Litbang Kemenkes RI. (2013). Riset Kesehatan Dasar.

Kemenkes. (2015). Infodatin Pusat Data dan Informasi Kementerian Kesehatan RI. https://pusdatin.kemkes.go.id/folder/view/0 1/structure-publikasi-pusdatin-infodatin.html

Komite Penanggulangan Kanker Payudara. (2015). Panduan Pelaksanaan Kanker Payudara.

http://kanker.kemkes.go.id/guidelines/PPK Payudara.pdf

Napitulu, M. C. S. (2010). Hubungan Dukungan Keluarga dengan Respon Cemas Anak Usia Sekolah terhadap Pemasangan Intravena di Rumah Sakit Advent Medan [Universitas Sumatera Utara]. http://repository.usu.ac.id/handle/1234567 89/24197 
Notoatmodjo, S. (2012). Promosi Kesehatan dan Perilaku Kesehatan. PT Rineka Cipta.

Novasari, D. H., Nugroho, D., \& Winarni, S. (2016). Hubungan Pengetahuan, Sikapdan Paparan Media Informasi dengan Praktik Pemeriksaan Payudara Sendiri (SADARI) Pada Santriwati Pondok Pesantren Al Islah Tembalang Semarang Tahun 2016. Jurnal Kesehatan Masyarakat, 4(4), 186194.

https://ejournal3.undip.ac.id/index.php/jkm/ article/view/13987/13523
Olfah, Y. (2013). Pengaruh Pelatihan Menggunakan Modul Tentang Kanker Payudara Terhadap Pengetahuan, Minat dan Perilaku Dalam Melakukan Pemeriksaan Payudara Sendiri di Provinsi Daerah Istimewa Yogyakarta.

WHO. (2012). World Health Statistic. Yayasan Kanker Indonesia. (2012). Kanker Payudara.

http://yayasankankerindonesia.org/ 